\title{
Complex Interaction between Obesity and Trauma
}

\author{
Amit Agrawal
}

\section{ABSTRACT}

Trauma and obesity are large-scale epidemics that can be associated with significant morbidity and mortality. In few studies, it has noted that there is the 'obesity paradox' (obesity has been found to be protective against mortality) due to certain causes, i.e. heart failure or cardiovascular disease. Subcutaneous fat can show great variability between individuals and increased subcutaneous fat may be protective against injuries by cushioning the internal abdominal organs against injurious forces in road traffic accidents. Many factors including the body fat distribution, body shape, and center of gravity may play an important role in the different injury patterns and severity of injury between men and women. A better understanding of how obesity influences trauma related injuries not only will help to improve the outcome but also foster the development of interventions to address the most salient and modifiable risk factors to reduce obesity related morbidity and mortality. In present article, we review the relevant literature with special considerations to understand the interactions of obesity and trauma with their impact on patient management and outcomes.

Keywords: Obesity, Trauma, Risk factor, Outcome.

How to cite this article: Agrawal A. Complex Interaction between Obesity and Trauma. Panam J Trauma Crit Care Emerg Surg 2014;3(3):109-113.

\section{Source of support: Nil}

\section{Conflict of interest: None}

\section{RESUMEN}

El trauma y la obesidad son epidemias a grande escala que pueden estar asociadas a una morbilidad y mortalidad significativa. En algunos estudios, se ha observado que existe una 'paradoja de la obesidad' (la obesidad se ha encontrado ser protectora contra la mortalidad) debido a ciertas causas, por ejemplo la insuficiencia cardíaca o la enfermedad cardiovascular. La grasa subcutánea puede mostrar una gran variabilidad entre los individuos y el aumento de la grasa subcutánea puede ser protectora contra lesiones amortiguando los órganos abdominales internos contra fuerzas perjudiciales en los accidentes de tráfico. Muchos factores, incluyendo la distribución de grasa corporal, la forma del cuerpo, y el centro de gravedad pueden jugar un papel importante en los

\footnotetext{
Professor

Department of Neurosurgery, Narayan Medical College and Hospital, Sasaram, Bihar, India

Corresponding Author: Amit Agrawal, Professor Department of Neurosurgery, Narayan Medical College and Hospital Sasaram, Bihar, India, Phone: 2658898, e-mail: dramitagrawal@gmail.com
}

diferentes patrones de lesiones y la gravedad de la lesión entre hombres y mujeres. Una mejor comprensión de cómo la obesidad influencia a las lesiones relacionadas a trauma no sólo contribuirá mejorar los resultados, sino también fomentar el desarrollo de intervenciones para abordar los factores de riesgos más sobresaliente y modificables para reducir la morbilidad y la mortalidad relacionada a la obesidad. En este artículo, revisamos la bibliografía pertinente con especial consideraciones para entender las interacciones de la obesidad y el trauma en su impacto en el manejo y los resultados del paciente.

Palabras claves: Obesidad, Trauma, Factores de riesgo, Resultado.

\section{INTRODUCTION}

The prevalence of obesity in many countries is continued to increase at an alarming rate and it is predicted that this trend will continue into the near future. ${ }^{1-6}$ Obesity is not only the independent risk factor for many medical problems including cardiovascular disease, type-2 diabetes, cancer, osteoarthritis of the knee and hip, and obstructive sleep apnea ${ }^{7-12}$ but also a well-established and important risk factor after major surgery and severe trauma. ${ }^{13-17}$ It has been shown that following trauma; obese patients sustain different injuries than lean patients and can have worse outcomes. ${ }^{18}$ Also the results of some studies indicate that obesity can be associated, albeit often marginally, with traumatic injuries, especially during participation in sports or motor vehicle accidents. ${ }^{19-24}$ In present article, we review the relevant literature with special considerations to understand the interactions of obesity and trauma with their impact on patient management and outcomes.

\section{DEFINITION}

Trauma and obesity are large-scale epidemics that can be associated with significant morbidity and mortality. ${ }^{25-27}$ Obesity is defined by a person's body mass index (BMI) and calculated by dividing a person's body mass (in kilograms) by the square of their stature (in meters). Obesity is defined as a BMI greater than $30 \mathrm{~kg} / \mathrm{m}^{2}$. Under weight $\left(\mathrm{BMI}<18.5 \mathrm{~kg} / \mathrm{m}^{2}\right)$, normal weight $\left(\mathrm{BMI}=18.5-24.9 \mathrm{~kg} / \mathrm{m}^{2}\right)$, overweight $\left(\mathrm{BMI}=25-29.9 \mathrm{~kg} / \mathrm{m}^{2}\right)$, obese $(\mathrm{BMI}=30-39.9$ $\mathrm{kg} / \mathrm{m}^{2}$ ) and morbidly obese $\left(\mathrm{BMI}>40 \mathrm{~kg} / \mathrm{m}^{2}\right){ }^{1,2,5,28,29}$ It was estimated that from 1980 to 2000 , the prevalence of obesity in United States increased from 14.4 to $30.5 \%$ and in 2005 to 2006; approximately 72 million Americans were 
obese. ${ }^{27}$ It has been estimated that about $35 \%$ of Americans are overweight (BMI of 25 to $29 \mathrm{~kg} / \mathrm{m}^{2}$ ); about $25 \%$ are obese (BMI of $30-39.9 \mathrm{~kg} / \mathrm{m}^{2}$ ); and $5 \%$ are morbidly obese $\left(\mathrm{BMI}>40 \mathrm{~kg} / \mathrm{m}^{2}\right){ }^{5}$ It was observed that in 2007 to 2008 , the prevalence of obesity was $32.2 \%$ among adult men and 35.5\% among adult women (where 'overweight' was defined as a BMI of 25.0 to 29.9 and 'obese' was defined as a BMI of 30.0 or higher). ${ }^{10}$ Although most of the studies rely on BMI as a measure of obesity, BMI is not the best measure of obesity as BMI misclassify adults with BMI below $30 \mathrm{~kg} / \mathrm{m}^{2}$., 30

\section{Fat is Good}

In few studies, it has noted that there is the 'obesity paradox,' whereby obesity has been found to be protective against mortality due to certain causes (i.e. heart failure or cardiovascular disease). ${ }^{31,32}$ Excess weight in elderly people (65 years and older) have been shown to offer protective benefits with respect to bone loss, osteoporosis, and hip fracture. ${ }^{33,34}$ Subcutaneous fat can show great variability between individuals and increased subcutaneous fat may be protective against injuries by cushioning the internal abdominal organs against injurious forces in road traffic accidents. ${ }^{22,35}$ However, it is not true for all the regions of the body, there is worsened injury severity in the extremities, particularly the lower extremities, with increased fat thickness. ${ }^{22}$

\section{Pathology}

Many factors including the body fat distribution, body shape, and center of gravity may play an important role in the different injury patterns and severity of injury between men and women. ${ }^{36}$ A large body mass with excess adiposity may contribute to motor vehicle crash, ${ }^{36}$ however the exact associations between obesity and body injuries are not well understood. ${ }^{37,38}$ Higher risk of injury in obese individuals may be attributed to differences in body shape, fat distribution, and center of gravity between obese and normal-weight subjects, and between men and women. ${ }^{38}$ Also the fat distribution and the amount and proportion of subcutaneous and visceral fat along with related waist and hip girths differs between men and women. ${ }^{39-42}$ Obese male drivers had a higher risk of injury in upper body regions, including the head, face, thorax, abdomen, and spine, than did obese female drivers. ${ }^{38}$ The higher risk of injury associated with a high BMI could be caused by combination of momentum effects, comorbidities of obesity, and the body's response to injury. ${ }^{21,43-47}$ Cabin designs in vehicles may not be optimal for obese drivers whose body size and shape differ considerably from the standard specifications and may contribute to an increased risk of injury. ${ }^{48,49}$ Apart from above mentioned factors obstructive sleep apnea is more prevalent in obese people and sleep apnea, sleepiness, and fatigue can potentially contributing injury factors for injuries..$^{50-54}$

\section{MANAGEMENT}

Obese patients represent a significant challenge to the acute care physicians as there are unique anatomic and physiologic considerations making them distinct from lean patients. ${ }^{2}$ As there is lack of studies and guidelines about the clinical approach to the obese trauma patient, presently we rely on either small series and case reports or general articles for the management of obese critical patients. ${ }^{55-59}$ As for any other trauma patient, the management of these patients begins with airway assessment and management. ${ }^{60-64}$ Despite inherent difficulties most obese patients should be able to be orotracheally intubated. ${ }^{65}$ If difficult airway is encountered, salvage techniques such as a laryngeal mask airway and awake fiberoptic intubation may be needed. ${ }^{62-65}$ Metabolic and nutritional support is an essential part of treating trauma patients and hemodynamic monitoring can be challenging in obese trauma patients. ${ }^{66}$ The metabolic syndromes associated with obesity needs to be recognized as these will lead to a prothrombotic state and it need to plan to take appropriate steps in an attempt to prevent deep venous thrombosis. ${ }^{67-69}$ Regarding nutritional needs of the critically injured obese patient, the surgeon must be aware of the paradoxical response of obese individuals as these patients rather than using abundant fat stores, obese patients will preferentially metabolize protein during the stressed state. ${ }^{70}$

\section{Complications}

It has been found that the patients with a BMI of greater than or equal to 30 suffered a twofold increase in mortality compared with lean patients (32\% vs 16\%) and a fourfold increase in the rate of multiple organ failure (13\% versus 3\%). ${ }^{49}$ Many studies have shown that increased body weight is associated with increased death in motor vehicle collisions. ${ }^{21,71,72}$ Morbid obesity has been identified as an independent risk factor for mortality following severe trauma, and the risk may be a two- to fourfold increase. ${ }^{59}$ However in few studies there was no statistically difference between the obese and non-obese patients in terms of mortality. ${ }^{18}$ Obese patients are at overall increased risk of complications including multiple system organ failure, adult respiratory distress syndrome and renal failure requiring dialysis. ${ }^{59,73}$ It has been speculated that increased mortality could be attributed at least par- 
tially to a higher rate of co-morbidities among the obese patients. ${ }^{21}$ Obesity has been linked to many conditions such as diabetes, hypertension, dyslipidemia, vascular disease, malignancy and liver disease ${ }^{74}$ but also obese patients are more prone for venous thromboembolism, chronic obstructive pulmonary disease, sleep-disordered breathing ${ }^{75,76}$ and surgical procedures related complications. ${ }^{77-79}$

\section{Prevention}

Injury prevention and obesity share a common goal of improving individual health, and public health programs to improve health should be coordinated. ${ }^{80}$ Presently, it is unknown that if weight reduction would lower injury rates. ${ }^{81}$ It has been suggested that weight reduction can prevent injuries or that prevention efforts should be targeted to overweight or obese individuals. ${ }^{82-84}$ To emphasize further, a better understanding of how differences in body composition affect regional body tolerance to high-energy trauma will help engineers to design vehicle safety systems capable enough to optimally protect each specific individual occupant. ${ }^{35}$

\section{CONCLUSION}

In summary, although obesity will remain a prevention and public health issue but it is expected that it will be an increasing part of daily surgical practice including trauma care. It is anticipated that the personals involved in acute trauma will need a core understanding of the pathophysiology of obesity and how obesity impacts the care of these critically ill and injured patients. A better understanding of how obesity influences trauma related injuries not only will help to improve the outcome but also foster the development of interventions to address the most salient and modifiable risk factors to reduce obesity related morbidity and mortality.

\section{REFERENCES}

1. Ogden CL, Carroll MD, Curtin LR, McDowell MA, Tabak CJ, Flegal KM. Prevalence of overweight and obesity in the United States, 1999-2004. JAMA 2006;295(13):1549-1555.

2. Byrnes MC, McDaniel MD, Moore MB, Helmer SD, Smith RS. The effect of obesity on outcomes among injured patients. J Trauma and Acute Care Surg 2005 Feb;58(2):232-237.

3. Reilly JJ, Methven E, McDowell ZC, Hacking B, Alexander D, Stewart L, et al. Health consequences of obesity: archives of disease in childhood 2003 Sep;88(9):748-752.

4. Lee EB, Ahima RS. Alteration of hypothalamic cellular dynamics in obesity. J Clin Invest 2012 Jan;122(1):22-25.

5. Hedley AA, Ogden CL, Johnson CL, Carroll MD, Curtin LR, Flegal KM. Prevalence of overweight and obesity among US children, adolescents, and adults, 1999-2002. JAMA 2004 Jun 16;291(23):2847-2850.
6. Flegal KM, Graubard BI, Williamson DF, Gail MH. Excess deaths associated with underweight, overweight, and obesity. JAMA 2005 Apr 20;293(15):1861-1867.

7. McCollum M, Ellis SL, Morrato EH, Sullivan PW. Prevalence of multiple cardiac risk factors in US adults with diabetes. Current Medical Research and Opinion 2006 Jun;22(6): 1031-1034.

8. Mokdad AH, Serdula MK, Dietz WH, Bowman BA, Marks JS, Koplan JP. The continuing epidemic of obesity in the United States. JAMA 2000 Oct 4;284(13):1650-1651.

9. Pi-Sunyer FX. Stepping down as Editor-in-Chief. Obesity research 2002 Dec;10(12):1201-1202.

10. Flegal KM, Carroll MD, Ogden CL, Curtin LR. Prevalence and trends in obesity among US adults, 1999-2008. JAMA 2010 Jan 20;303(3):235-241.

11. Hubert HB, Feinleib M, McNamara PM, Castelli WP. Obesity as an independent risk factor for cardiovascular disease: a 26-year follow-up of participants in the Framingham Heart Study. Circulation 1983 May;67(5):968-977.

12. Renehan AG, Tyson M, Egger M, Heller RF, Zwahlen M. Bodymass index and incidence of cancer: a systematic review and meta-analysis of prospective observational studies. Lancet 2008 Feb 16;371(9612):569-578.

13. Serrano PE, Khuder SA, Fath JJ. Obesity as a risk factor for nosocomial infections in trauma patients. J American College Surg 2010 Jul;211(1):61-67.

14. Christmas AB, Reynolds J, Wilson AK, Franklin GA, Miller FB, Richardson JD, et al. Morbid obesity impacts mortality in blunt trauma. Am Surgeon 2007 Nov;73(11):1122-1125.

15. Diaz JJ, Norris PR, Collier BR, Berkes MB, Ozdas A, May AK, Miller RS, Morris JA Jr. Morbid obesity is not a risk factor for mortality in critically ill trauma patients. J Trauma 2009 Jan; 66(1):226-231.

16. Nelson JA, Loredo JS, Acosta JA. The obesity-hypoventilation syndrome and respiratory failure in the acute trauma patient. J Emerg Med 2011 Apr;40(4):e67-69.

17. Lobstein T, Baur L, Uauy R, TaskForce IIO. Obesity in children and young people: a crisis in public health. Obesity Review 2004 May;5 Suppl 1:4-104.

18. Brown C, Velmahos G. The consequences of obesity on trauma, emergency surgery and surgical critical care. World J Emerg Surg 2006 Sep 6;1:27.

19. Trifiletti LB, Shields W, Bishai D, McDonald E, Reynaud F, Gielen A. Tipping the scales: obese children and child safety seats. Pediatrics 2006 Apr;117(4):1197-1202.

20. Whitlock G, Norton R, Clark T, Jackson R, MacMahon S. Is body mass index a risk factor for motor vehicle driver injury? A cohort study with prospective and retrospective outcomes. Int J Epidemiol 2003 Feb;32(1):147-149.

21. Mock CN, Grossman DC, Kaufman RP, Mack CD, Rivara FP. The relationship between body weight and risk of death and serious injury in motor vehicle crashes. Accident, Analysis and Prevention 2002;34(2):221-228.

22. Arbabi S, Wahl WL, Hemmila MR, Kohoyda-Inglis C, Taheri PA, Wang SC. The cushion effect. J Trauma 2003;54(6): 1090-1093.

23. Hagel BE, Fick GH, Meeuwisse WH. Injury risk in men's Canada West University football. Am J Epidemiol 2003; 54(6):1090-1093.

24. Kaplan TA, Digel SL, Scavo VA, Arellana SB. Effect of obesity on injury risk in high school football players. Clin J Sport Med 1995;5(1):43-47. 
25. Caballero B. The global epidemic of obesity: an overview. Epidemiologic Reviews 2007;29:1-5.

26. Mokdad AH, Ford ES, Bowman BA, Dietz WH, Vinicor F, Bales VS, et al. Prevalence of obesity, diabetes, and obesityrelated health risk factors, 2001. JAMA 2003;289(1):76-79.

27. Ogden CL, Carroll MD, McDowell MA, Flegal KM. Obesity among adults in the United States-no statistically significant chance since 2003-2004. NCHS Data Brief 2007;(1):1-8.

28. Panel NOEIE on the identification, evaluation, and treatment of overweight and obesity in adults. Clinical guidelines on the identification, evaluation, and treatment of overweight and obesity inadults—-theevidencereport. Obes Res 1998;6(Suppl2): 51S-209S

29. Mei Z, Grummer-Strawn LM, Pietrobelli A, Goulding A, Goran MI, Dietz WH. Validity of body mass index compared with other body-composition screening indexes for the assessment of body fatness in children and adolescents. Am J Clin Nutr 2002;75(6):978-985.

30. Frankenfield DC, Rowe WA, Cooney RN, Smith JS, Becker D. Limits of body mass index to detect obesity and predict body composition. Nutrition (Burbank, Los Angeles County, Calif) 2001;17(1):26-30.

31. Lavie CJ, Milani RV, Ventura HO. Obesity and cardiovascular disease: risk factor, paradox, and impact of weight loss. J Am College of Cardiol 2009;53(21):1925-1932.

32. Uretsky S, Messerli FH, Bangalore S, Champion A, CooperDehoff RM, Zhou Q, et al. Obesity paradox in patients with hypertension and coronary artery disease. Am J Med 2007; 120(10):863-870.

33. Felson DT, Zhang Y, Hannan MT, Anderson JJ. Effects of weight and body mass index on bone mineral density in men and women: the Framingham study. J Bone and Mineral Res 1993;8(5):567-573.

34. Rössner S. Obesity in the elderly-a future matter of concern? Obesity reviews: J Int Assoc Study Obesity 2001;2(3):183-188.

35. Wang SC, Bednarski B, Patel S, Yan A, Kohoyda-Inglis C, Kennedy $\mathrm{T}$, et al. Increased depth of subcutaneous fat is protective against abdominal injuries in motor vehicle collisions. Annual proceedings/Association for the Advancement of Automotive Medicine Association for the Advancement of Automotive Medicine 2003;47:545-559.

36. Zhu S, Layde PM, Guse CE, Laud PW, Pintar F, Nirula R, et al. Obesity and risk for death due to motor vehicle crashes. Am J Public Health 2006;96(4):734-739.

37. Tagliaferri F, Compagnone C, Yoganandan N, Gennarelli TA. Traumatic brain injury after frontal crashes: relationship with body mass index. J Trauma 2009;66(3):727-729.

38. Zhu S, Kim J-E, Ma X, Shih A, Laud PW, Pintar F, et al. BMI and risk of serious upper body injury following motor vehicle crashes: concordance of real-world and computer-simulated observations. PLoS Medicine 2010;7(3):e1000250.

39. Vague J. Sexual differentiation. A determinant factor of the forms of obesity. 1947. Obesity Res 1996;4(2):201-203.

40. Enzi G, Gasparo M, Biondetti PR, Fiore D, Semisa M, Zurlo F. Subcutaneous and visceral fat distribution according to sex, age, and overweight, evaluated by computed tomography. Am J Clin Nutrit 1986;44(6):739-746.

41. Ross R, Shaw KD, Rissanen J, Martel Y, de Guise J, Avruch L. Sex differences in lean and adipose tissue distribution by magnetic resonance imaging: anthropometric relationships. Am J Clin Nutrit 1994;59(6):1277-1285.

42. Larsson I, Bertéus Forslund H, Lindroos AK, Lissner L, Näslund I, Peltonen M, et al. Body composition in the SOS
(Swedish Obese Subjects) reference study. Int J Obesity and Related Metabolic Disorders 2004;28(10):1317-1324.

43. Stoohs RA, Guilleminault C, Itoi A, Dement WC. Traffic accidents in commercial long-haul truck drivers: the influence of sleep-disordered breathing and obesity. Sleep 1994;17(7): 619-623.

44. Terán-Santos J, Jiménez-Gómez A, Cordero-Guevara J. The association between sleep apnea and the risk of traffic accidents. Cooperative Group Burgos-Santander. New England J Med 1999;340(11):847-851.

45. Barbé, Pericás J, Muñoz A, Findley L, Antó JM, Agustí AG. Automobile accidents in patients with sleep apnea syndrome. An epidemiological and mechanistic study. Am J Res Crit Care Med 1998;158(1):18-22.

46. Yee B, Campbell A, Beasley R, Neill A. Sleep disorders: a potential role in New Zealand motor vehicle accidents. Int Med J 2002;32(7):297-304.

47. George CF. Reduction in motor vehicle collisions following treatment of sleep apnoea with nasal CPAP. Thorax 2001;56(7): 508-512.

48. Zizza C, Herring AH, Stevens J, Popkin BM. Length of hospital stays among obese individuals. Am J Public Health 2004;94(9):1587-1591.

49. Neville AL, Brown CVR, Weng J, Demetriades D, Velmahos GC. Obesity is an independent risk factor of mortality in severely injured blunt trauma patients. Archives of Surgery (Chicago, Ill :1960). 2004;139(9):983-987.

50. Gami AS, Hodge DO, Herges RM, Olson EJ, Nykodym J, Kara T, et al. Obstructive sleep apnea, obesity, and the risk of incident atrial fibrillation. J Am College of Cardiol 2007; 49(5):565-571.

51. Vorona RD, Winn MP, Babineau TW, Eng BP, Feldman HR, Ware JC. Overweight and obese patients in a primary care population report less sleep than patients with a normal body mass index. Archives of Internal Medicine 2005;165(1):25-30.

52. Swaen GMH, van Amelsvoort LPGM, Bültmann U, Slangen JJM, Kant IJ. Psychosocial work characteristics as risk factors for being injured in an occupational accident. J Occup Environ Med 2004;46(6):521-527.

53. Garbarino S, De Carli F, Mascialino B, Beelke M, Nobili L, Squarcia S, et al. Sleepiness in a population of Italian shiftwork policemen. J Human Ergology 2001;30(1-2):211-216.

54. Kohatsu ND, Tsai R, Young T, Vangilder R, Burmeister LF, Stromquist AM, et al. Sleep duration and body mass index in a rural population. Archives of Internal Medicine 2006; 166(16):1701-1705.

55. Flancbaum L, Choban PS. Surgical implications of obesity. Annual Review of Med 1998;49:215-234.

56. Marik PE, Zaloga GP. Gastric versus post-pyloric feeding: a systematic review. Critical Care (London, England) 2003; 7(3):R46-51.

57. Grant P, Newcombe M. Emergency management of the morbidly obese. Emergency Medicine Australasia 2004;16(4): 309-317.

58. Pieracci FM, Barie PS, Pomp A. Critical care of the bariatric patient. Critical Care Med 2006;34(6):1796-1804.

59. Meroz Y, Gozal Y. Management of the obese trauma patient. Anesthesiol Clinics 2007;25(1):91-98.

60. Williamson JA, Webb RK, Szekely S, Gillies ER, Dreosti AV. The Australian Incident Monitoring Study. Difficult intubation: an analysis of 2000 incident reports. Anaesthesia and Intensive Care 1993;21(5):602-607. 
61. Combes X, Jabre P, Jbeili C, Leroux B, Bastuji-Garin S, Margenet A, et al. Prehospital standardization of medical airway management: incidence and risk factors of difficult airway. Academic Emergency Medicine 2006;13(8):828-834.

62. Jabre P, Combes X, Leroux B, Aaron E, Auger H, Margenet A, et al. Use of gum elastic bougie for prehospital difficult intubation. Am J Emergency Med 2005;23(4):552-555.

63. Agrò F, Frass M, Benumof J, Krafft P, Urtubia R, Gaitini L, et al. The esophageal tracheal combitube as a non-invasive Alternative to endotracheal intubation: a review. Minerva anestesiologica 2001;67(12):863-874.

64. Hagberg CA, Westhofen P. A two-person technique for fiberscope-aided tracheal extubation/reintubation in intensive care unit (ICU) patients. J Clinical Anesthesia 2003;15(6): 467-470.

65. Keller C, Brimacombe J, Kleinsasser A, Brimacombe L. The Laryngeal Mask Airway ProSeal (TM) as a temporary ventilatory device in grossly and morbidly obese patients before laryngoscope-guided tracheal intubation. Anesthesia and Analgesia 2002;94(3):737-740.

66. Thompson EC, Wilkins HE, Fox VJ, Fernandez LG. Insufficient length of pulmonary artery introducer in an obese patient. Archives of Surgery (Chicago, Ill : 1960). 2004;139(7):794-796.

67. Nasraway SA, Hudson-Jinks TM, Kelleher RM. Multidisciplinary care of the obese patient with chronic critical illness after surgery. Critical Care Clinics 2002;18(3):643-657.

68. Kim V,Spandorfer J. Epidemiology of venous thromboembolic disease. Emergency Medicine Clinics of North America. 2001; 19(4):839-859.

69. Meissner MH, Chandler WL, Elliott JS. Venous thromboembolism in trauma: a local manifestation of systemic hypercoagulability? J Trauma 2003;54(2):224-231.

70. Jeevanandam M, Young DH, Schiller WR. Obesity and the metabolic response to severe multiple trauma in man. J Clin Invest 1991;87(1):262-269.

71. Choban PS, Weireter LJ, Maynes C. Obesity and increased mortality in blunt trauma. J Trauma 1991;31(9):1253-1257.

72. Moran SG, McGwin G, Reiff DA, Rue LW. The association between body habitus, restraint use, and fatality in motor vehicle collisions. Annual proceedings/Association for the Advancement of Automotive Medicine Association for the Advancement of Automotive Medicine 2001;45:107-123.
73. Zein JG, Albrecht RM, Tawk MM, Kinasewitz GT. Effect of obesity on mortality in severely injured blunt trauma patients remains unclear. Archives of Surgery (Chicago, Ill : 1960) 2005;140(11):1130-1131.

74. Shenkman Z, Shir Y, Brodsky JB. Perioperative management of the obese patient. Br J Anaesthesia 1993;70(3):349-359.

75. Moore K. Hypothermia in trauma. J Trauma Nursing 2008; 15(2):62-64.

76. Dossett LA, Heffernan D, Lightfoot M, Collier B, Diaz JJ, Sawyer RG, et al. Obesity and pulmonary complications in critically injured adults. Chest 2008;134(5):974-980.

77. Wilson JA, Clark JJ. Obesity: impediment to postsurgical wound healing. Advances in Skin and Wound Care 2004; 17(8):426-435.

78. Winiarsky R, Barth P, Lotke P. Total knee arthroplasty in morbidly obese patients. J Bone and Joint Surg Am Volume 1998;80(12):1770-1774.

79. Brandt M, Harder K, Walluscheck KP, Schöttler J, Rahimi A, Möller F, et al. Severe obesity does not adversely affect perioperative mortality and morbidity in coronary artery bypass surgery. Eur J Cardiothoracic Surgery 2001;19(5): 662-666.

80. Pollack KM. An injury prevention perspective on the childhood obesity epidemic. Preventing Chronic Disease 2009;6(3).

81. Froom P, Melamed S, Kristal-Boneh E, Gofer D, Ribak J. Industrial accidents are related to relative body weight: the Israeli CORDIS study. Occupational and Environment Med 1996;53(12):832-835.

82. Chau N, Gauchard GC, Siegfried C, Benamghar L, Dangelzer J-L, Français M, et al. Relationships of job, age, and life conditions with the causes and severity of occupational injuries in construction workers. International Archives of Occupational and Environmental Health 2004;77(1):60-66.

83. Myers AH, Baker SP, Li G, Smith GS, Wiker S, Liang KY, et al. Back injury in municipal workers: a case-control study. Am J Public Health 1999;89(7):1036-1041.

84. Bhattacherjee A, Chau N, Sierra CO, Legras B, Benamghar L, Michaely J-P, et al. Relationships of job and some individual characteristics to occupational injuries in employed people: a community-based study. J Occupational Health 2003;45(6): 382-391. 